International Journal of Agriculture, Environment and Bioresearch

Vol. 06, No. 03; 2021

ISSN: $2456-8643$

\title{
COMPARATIVE STUDY OF DROUGHT STRESS TOLERANCE OF FOUR PROVENANCES OF Anacardium occidentale L. GROWN UNDER SEMI- CONTROLLED CONDITIONS
}

\author{
Pape Ibrahima Djighaly ${ }^{1 *}$, Seydou Ndiaye ${ }^{1}$, Joseph Saturnin Dieme ${ }^{1}$, Fatou Dieng ${ }^{1}$, Moustapha Gueye ${ }^{2}$, \\ Arlette Zaiya Zazou ${ }^{4}$, Amadou Mbarrick Diarra ${ }^{1}$ and Fode Amata Dramé ${ }^{3}$ \\ ${ }^{1}$ Agroforestry Department, Assane Seck University, Agroforestry and Ecology Laboratory (LAFE), BP 523, \\ Ziguinchor, Senegal, \\ ${ }^{2}$ Senegalese Institute of Agricultural Research, National Center for Agronomic Research of Bambey, BP 53, \\ Diourbel, Senegal, \\ ${ }^{3}$ Geography Department, Assane Seck University, Geomatics and Environment Laboratory, BP 523, Ziguinchor, \\ Senegal, \\ ${ }^{4}$ Institute of Agricultural Research for Development (IRAD), 2123, Yaounde, Cameroun
}

https://doi.org/10.35410/IJAEB.2021.5642

\begin{abstract}
The adaptation of Anacardium occidentale L. to water deficit conditions has become essential in the context of climate change in Casamance, Senegal. Water deficit is one of the main causes that strongly affect the productivity of woody species. Thus, the promotion of tolerant varieties that can withstand the uncertainty of rainfall and its deficits is a solution to adapt to the effects of climate change.

The study of the tolerance of four provenances of Anacardium occidentale L under drought stress conditions $(12.5 \%, 25 \%, 50 \%$ and $100 \%$ of field capacity) was carried out in a semi-controlled environment. The measurement of height, total dry biomass, collar diameter and root length and relative water content, allowed us to obtain the results on the growth and physiological reactions of Anacardium occidentale provenances under water stress. At a high level of drought stress (12.5\%), the best growth was obtained with plants from the Ziguinchor provenance, which had higher survival rates, heights, collar diameters and relative water content than the Kolda, Sédhiou and Goudomp provenances. These results show that the Ziguinchor plants provenance is more tolerant to water stress than the other provenances tested. This study recommends the use of the Ziguinchor Anacardium occcidentale provenance to fight against the effects of climate change in Casamance (Senegal).
\end{abstract}

Keywords: Water stress, provenance, adaptation, Anacardium occcodentale, tolerance.

\section{INTRODUCTION}

Globally, arid and semi-arid areas account for 30\% of the land area [1]. In these environments, precipitation is limited in time and space [2]. Thus, drought is one of the factors limiting agricultural and forestry production in arid and semi-arid areas of West Africa [3]. Indeed, in these regions, plants are faced with several stresses in particular water stress that can have various origins: drought (water deficit) and flooding (excess water). The water deficit results in a low availability of free water, which plays an essential role in the transport and accumulation of 
solutes necessary for plant metabolism [4]. To cope with this water deficit, plants develop several morphological, anatomical, metabolic, physiological, and molecular adaptive mechanisms that allow them to maintain their growth, development, and biomass production [5].

Also, arid and semi-arid areas are particularly exposed to drought stress due to the effects of notable climate change [6]. They are also highly attractive areas due to their economic, tourism and ecological interests. They are subject to many anthropogenic pressures (e.g., use conflicts, agricultural activities, deforestation). Finding solutions for the preservation of these environments is becoming a major challenge. Thus, finding plant species adapted to these environments is essential in order to maintain an acceptable level of productivity.

In Senegal, Anacardium occidentale L. was introduced in 1914 for the reforestation of degraded areas [7]. The species is of particular economic interest because of the use of its nut by the cosmetic and food industries.

Casamance is one of the main cashew nut production areas in Senegal and since the early 1970s, it has been subject to strong climatic variability with environmental and socio-economic consequences [8]. The environmental consequences are related to the decrease in rainfall, flooding during the rainy seasons, land salinization, and temperature increase $[8,9,10]$.

Therefore, studying the mechanisms of adaptation of the species to water stress and finding the most drought-tolerant provenance is a way to fight the effects of climate change on the productivity of the species.

The aim of this study is to compare the water stress tolerance of four provenances of Anacardium occidentale in order to propose to producers and decision-makers the most adapted provenance to the changing conditions of Casamance, the principal production area in Senegal.

\section{MATERIALS AND METHODS}

\subsection{Site of provenances and characteristic of the types of provenances}

Seeds of Anacardium occidentale used in this study were collected in four departments of the natural region of Casamance (Figure 1). 


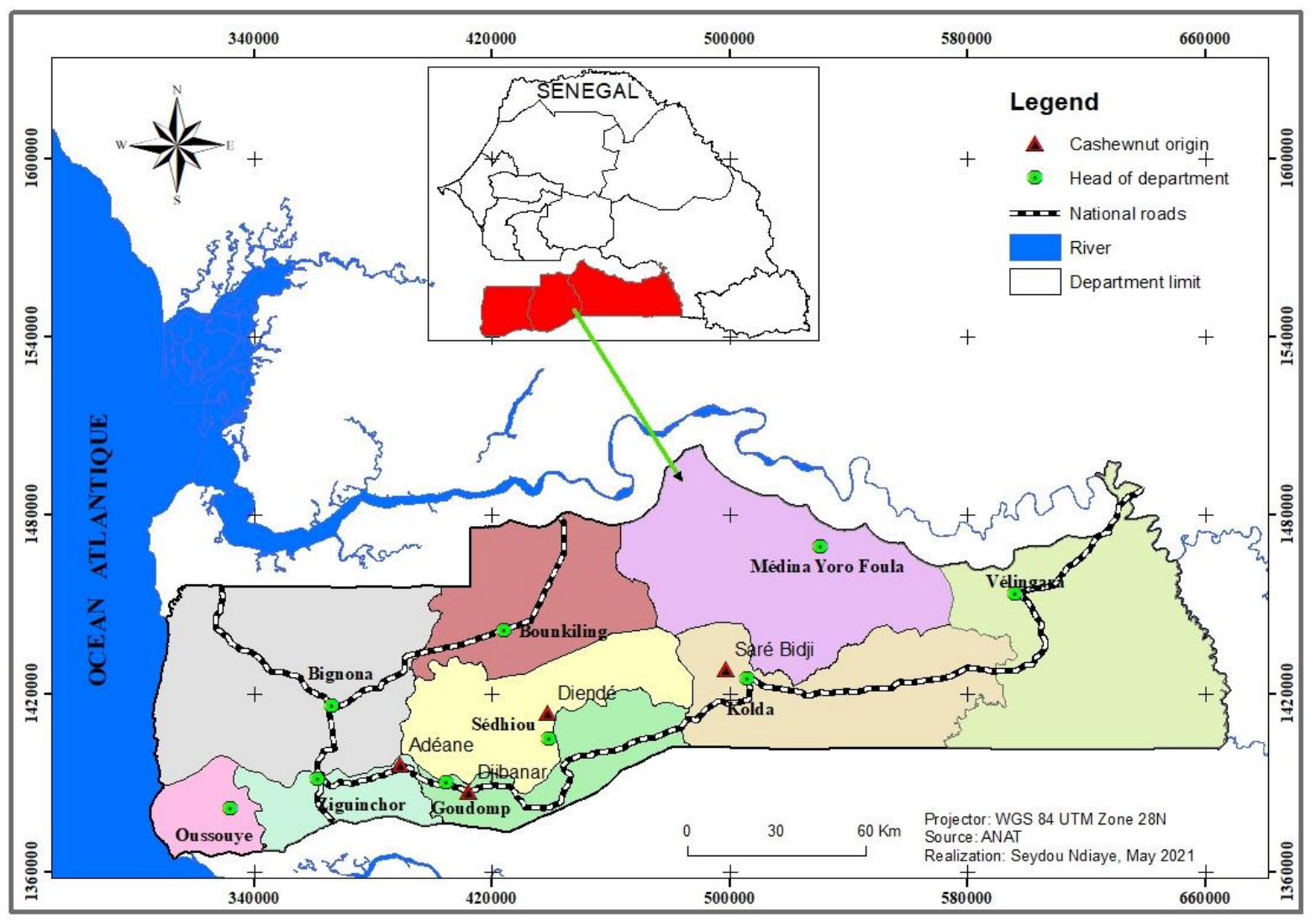

Figure 1: Lacalization of Anacardium occidentale seeds provenances

These are the departments of Kolda $\left(12^{\circ} 53^{\prime} 00^{\prime \prime} \mathrm{N}, 1^{\circ} 57^{\prime} 00^{\prime \prime} \mathrm{W}\right)$, Sedhiou $\left(12^{\circ} 42^{\prime} 29^{\prime \prime} \mathrm{N}\right.$, $\left.15^{\circ} 33^{\prime} 25^{\prime \prime} \mathrm{W}\right)$, Goudomp (12 $\left.34^{\prime} 40^{\prime \prime} \mathrm{N}, 15^{\circ} 52^{\prime} 20^{\prime \prime} \mathrm{W}\right)$ and Ziguinchor $\left(12^{\circ} 33^{\prime} 40^{\prime \prime} \mathrm{N}, 16^{\circ} 17^{\prime} 00^{\prime \prime}\right.$ W). The average annual rainfall in this region varies from 900 to more than $1300 \mathrm{~mm}$ and the climate is Sudano-Guinean. This region is the most important cashew nut production area in Senegal. Table 1 presents the main characteristics of their nuts.

Table 1: Characteristics of the nuts

\begin{tabular}{|l|l|l|l|}
\hline Provenances & Sizes $(\mathbf{m m})$ & Weight $(\mathbf{g})$ & KOR $(\mathbf{l b s})$ \\
\hline Ziguinchor & $33-36$ & $7-9$ & $50 \mathrm{lbs}$ \\
\hline Goudomp & $33-36$ & $6-7$ & $49 \mathrm{lbs}$ \\
\hline Sédhiou & $28-35$ & $6-8$ & $49 \mathrm{lbs}$ \\
\hline Kolda & $29-33$ & $5-6$ & $46 \mathrm{lbs}$ \\
\hline
\end{tabular}




\subsection{Seedling growth, experimental design and application of stress level}

The experiment was carried out at Assane Seck University under semi-controlled conditions (about $30^{\circ} \mathrm{C}$ ). A direct semi was done in black nursery pots of size (PM $25 \times 12 \times 50$ ) filled with the same amount of soil and plants were harvested three months after stress application.

At the beginning of the experiment (November 01, 2020), the plants were watered with tap water until 45 days to allow the young plants to be robust. After 45 days, the plants were watered with different levels of watering $(12.5 \%, 25 \%, 50 \%$ and $100 \%)$ relative to the field capacity of soil. The field capacity was determined from pots containing $1.5 \mathrm{~kg}$ of dry soil used in the experiment $(\mathrm{P} 1=$ dry soil weight $)$. Then these sheaths were watered until saturation and left to drain. After $24 \mathrm{~h}$, the sheaths are weighed again $\mathrm{P} 2(\mathrm{P} 2=$ weight at saturation). The difference between $\mathrm{P} 2$ and $\mathrm{P} 1$ is the amount of water retained by the soil. The field capacity (FC) is estimated by the following equation:

$\mathrm{FC}=[(\mathrm{P} 2-\mathrm{P} 1) / \mathrm{P} 1] \times 100$

Watering was done every four days. For the first 45 days the plants of each stress level were watered with the same amount of water corresponding to the FC. At the beginning of stress three pots from each stress level were weighed and the average of the three to obtain the M1 weight. This M1 weight is the reference weight. The following week, before watering, the weight of these same potss will be determined to obtain a M2 weight. The difference M1-M2 will represent the amount of water to be added to maintain the required stress level. Because of the evolution of the biomass of the plants, the quantity of water brought to each pot and the frequency of watering were readjusted every 15 days. An experimental randomized block design was carried out with two factors: plant provenances (Ziguinchor, Kolda, Sédhiou and Goudomp) and watering levels $(12.5 \%, 25 \%, 50 \%$ and $100 \%), 16$ treatments ( 4 X 4) with five replications per treatment. The experiment lasted three months after application of the stress.

\subsection{Calculation of survival rate and measurement of height, aerial and root biomass and root length}

For each provenance and cultivation treatment, the survival rate was determined using the following formula:

Survival rate $(\%)=\frac{\text { number of surviving plants }}{\text { number total of plants }} * 100$

The height growth of the plants was measured every two weeks with a graduated ruler. Plants were harvested after 4 months of cultivation. The aerial and root parts were separated, the roots were washed with tap water and the root length was determined using a graduated caliper. The samples were then oven dried at $70^{\circ} \mathrm{C}$ for $72 \mathrm{~h}$. The dry biomass of each type of sample was weighed using a precision balance (Sartorium, precision $0.1 \mathrm{mg}$ )

\subsection{Relative water content (RWC)}


The evolution of the water status of Anacardium occidentale plants subjected to different levels of stress was carried out by monitoring their relative water content (RWC). For each plant, a fragment of stem was cut and weighed to obtain the weight of fresh material Wf. This fragment was then immersed in a $15 \mathrm{ml}$ Falcon tube containing distilled water and kept in the dark at room temperature for 24 hours. It is then removed and weighed to obtain the turgor weight or saturation weight Wt. After weighing, the stem pieces were oven dried to a constant weight corresponding to the dry weight $\mathrm{Wd}$. The relative water content was obtained according to the formula:

$$
\text { RWC }(\%)=\frac{(w f-w d)}{(W t-w d)} * 100
$$

\subsection{Statistical analysis}

The measured parameters (Survival rate, height, total biomass, root length, RWC of Anarcadium occidentale plants were statistically processed using R 3.4.2 software. A two-factor analysis (provenances and watering levels) was performed using the Student-Newman and Keuls test (SNK) at $\mathrm{P}<0.05$.

\section{RESULTS}

Analysis of variance (ANOVA) showed a significant effect of water stress and provenance on all parameters studied (survival rate, height, crown diameter, root length, total biomass and relative water content). A significant effect of water stress $\times$ provenance interaction was observed on total biomass of Anacardium occidentale (Table 2).

Table 2: Interaction test between the factors "Provenances", «Drought stress" and the measured parameters

\begin{tabular}{|llllll|}
\hline & Height & $\begin{array}{l}\text { Collar } \\
\text { diameter }\end{array}$ & $\begin{array}{l}\text { Total dry } \\
\text { biomass }\end{array}$ & Root lenght & $\begin{array}{l}\text { Relative water } \\
\text { content (RWC) }\end{array}$ \\
\hline Provenances (P) & ++ & ++ & ++ & + & + \\
Drought stress (S) & ++ & + & ++ & ++ & ++ \\
$\mathrm{P} \times \mathrm{S}$ & $\mathrm{ns}$ & $\mathrm{ns}$ & + &. &. \\
\hline
\end{tabular}

.,,+++ and +++ indicate significant differences at $\mathrm{p}<0.05,0.01$ and 0.001 respectively; ns: no significant difference

\subsection{Impact of water stress on plant survival rate}

In all four provenances, signs of damage and mortality were observed at stress levels of $25 \%$. The highest survival rate was noted with the Ziguinchor provenance. The Goudomp provenance appeared to be in an intermediate position while the Kolda and Sédhiou provenances showed the greatest mortality. 
Plants from the Ziguinchor provenance had a survival rate of $100 \%$ and $60 \%$ respectively at $25 \%$ and $12.5 \%$ watering levels after four months of cultivation (Table 3 ).

Table 3: Survival rate of Anacardium occidentale provenances according to water stress $(100 \%, 50 \%, 25$ and $12.5 \%)$

\begin{tabular}{|lllll|}
\hline \multirow{2}{*}{ Water stress } & \multicolumn{3}{l|}{ Survival rate (\%) } \\
\cline { 2 - 5 } & Ziguinchor & Goudomp & Sédhiou & Kolda \\
\hline Not stressed at $100 \%$ FC & $100 \mathrm{a}$ & $100 \mathrm{a}$ & $100 \mathrm{a}$ & $100 \mathrm{a}$ \\
Stressed at 50\% FC & $100 \mathrm{a}$ & $100 \mathrm{a}$ & $100 \mathrm{a}$ & $100 \mathrm{a}$ \\
Stressed at $25 \%$ FC & $100 \mathrm{a}$ & $80 \mathrm{a}$ & $90 \mathrm{a}$ & $50 \mathrm{~b}$ \\
Stressed at $12,5 \%$ FC & $60 \mathrm{a}$ & $50 \mathrm{~b}$ & $40 \mathrm{~b}$ & $30 \mathrm{~b}$ \\
\hline
\end{tabular}

For each column, values followed by the same letter are not significantly different according to the 5\% SNK test. FC: Field capacity of soil

\subsection{Impact of water stress on plant height}

Plants from the four provenances subjected to different levels of watering $(100 \%, 50 \%, 25 \%$ and $12.5 \%$ ) expressed overall quite different growth patterns in height, with Ziguinchor provenance showing significantly higher growth than those from Kolda and Sédhiou. The growth in height of Ziguinchor provenance was not significantly different from that of Goudomp provenance. The increase in the level of drought stress had a depressive effect on the growth of the four provenances with a very significant decrease in the height of the plants from the first days of $\mathrm{NaCl}$ application (Figure 2). Plants of Kolda and Sédhiou provenances were more affected by the application of water stress. 


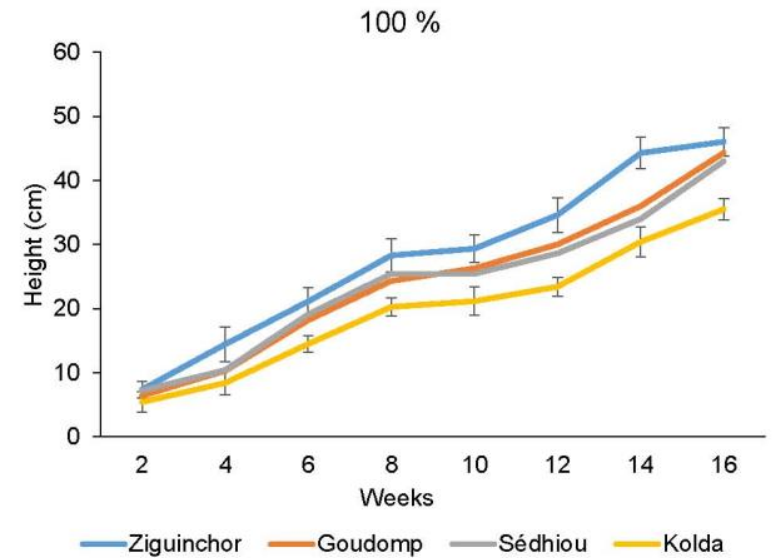

$25 \%$

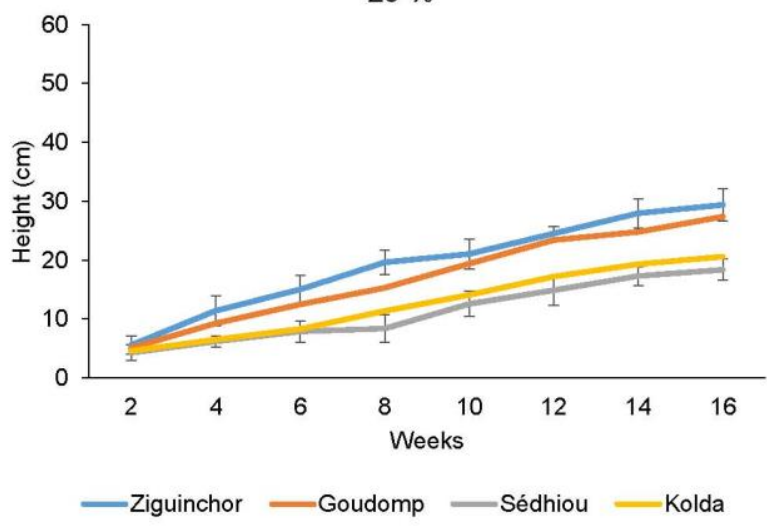

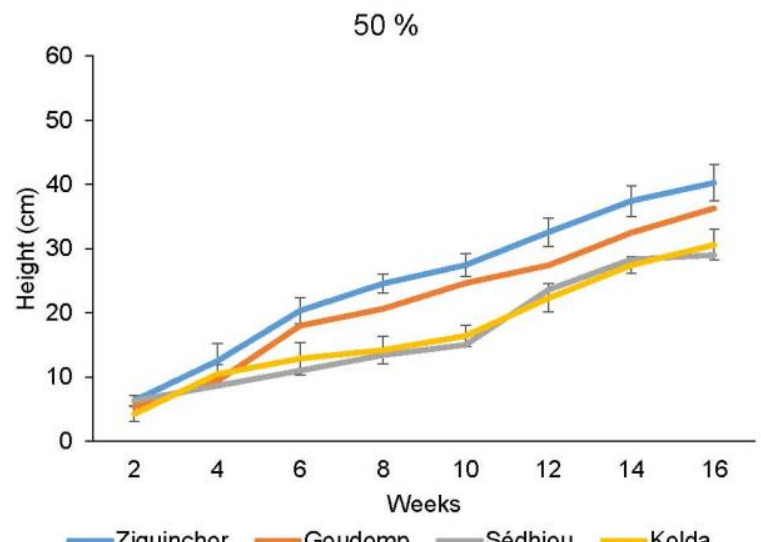

$12.5 \%$

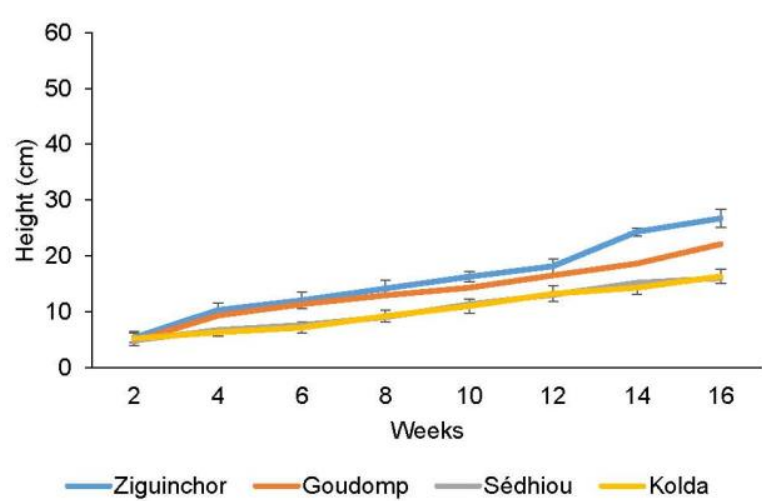

Figure 2: Plants height growth as a function of provenance and drought stress level.

Error bars represent standard deviations $(n=5)$.

\subsection{Impact of water stress on collar diameter and root length of plants}

The collar diameter of four provenances of Anacardium occidentale was evaluated after four months of cultivation under semi-controlled conditions. The results obtained showed a depressive effect of water stress on collar diameter (Figure 3a). The highest collar diameters were obtained with the Ziguinchor provenance at $100 \%, 50 \%, 25 \%$ and $12.5 \%$. However, at $12.5 \%$ stress levels, plants from Ziguinchor provenance had collar diameters $52.30 \%, 38.46 \%$ and $7.69 \%$ higher than those from Kolda, Sédhiou and Goudomp respectively.

The root length of Anacardium occidentale plants varied according to provenance and duration of water stress. Thus, the Ziguinchor and Goudomp provenances showed the higher root lengths at all levels of water stress. At the stress level where damage was most observed (12.5\%), plants from Ziguinchor provenance showed an increase of $30.58 \%, 47.71 \%$ and $26.79 \%$ in root length respectively compared to Kolda, Sédhiou and Goudomp provenances (Figure 3b). 

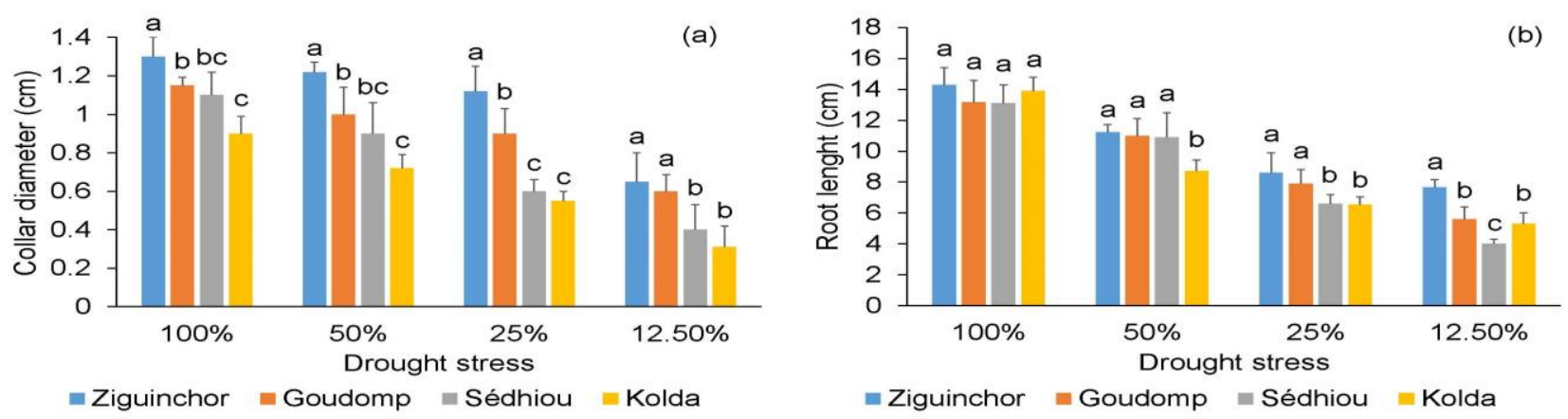

Figure 3: Collar diameter (a) and root length (b) of plants as a function of provenance and drought stress level.

For each water stress level, histograms with the same letters are not statistically different according SNK test at $P<0.05$. Error bars represent standard deviations $(n=5)$.

\subsection{Impact of water stress on total dry biomass and relative water content of plants}

The total dry biomass of Anacardium occidentale was determined after four months of water stress. The results obtained indicate a significant decrease in total dry biomass at $25 \%$ and $12.5 \%$ (Figure 4a). Plants from Ziguinchor and Goudomp provenances had a significantly higher total dry biomass than plants from the Kolda and Sédhiou provenances in the absence and presence of water stress.

Relative water content also decreased with increasing levels of water stress. Relative water content was higher in plants from Ziguinchor provenance compared to plants from the Kolda and Sédhiou provenances. At a stress level of $12.5 \%$, plants from the Ziguinchor provenance had a higher relative water content of $47.74 \%, 33.54 \%$ and $25.216 \%$ respectively compared to the Kolda, Sédhiou and Goudomp provenances (Figure 4b).
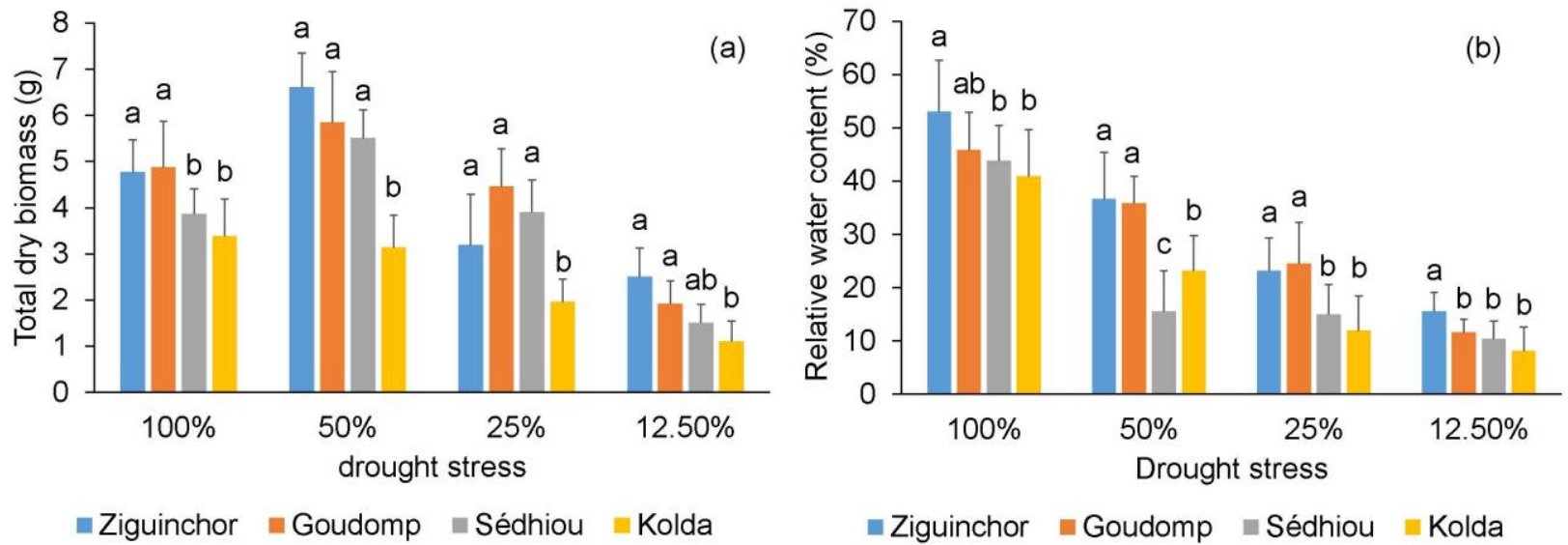
Vol. 06, No. 03; 2021

ISSN: $2456-8643$

Figure 5: Total dry biomass and relative water content of plants as a function of provenance and drought stress level.

For each water stress level, histograms with the same letters are not statistically different according SNK test at $\mathrm{P}<0.05$. Error bars represent standard deviations $(\mathrm{n}=5)$.

\section{DISCUSSION}

The application of water stress had a depressive effect on the survival rate of the four Anacardium occidentale provenances. Plant survival rate and growth varied among the provenances and the duration of the water stress. A higher survival rate was observed in plants from Ziguinchor provenance after four months under water stress application. These results suggest that plants from Ziguinchor provenance are more tolerant to water stress than those from Kolda, Sédhiou and Goudomp provenances.

This resistance of plants from Ziguinchor could be linked to a better regulation of its relative water content at severe levels of water stress. Studies have reported that when drought stress is sensed by plants, the first short-term response is a reduction in stomatal conductance to avoid water loss through transpiration and in the medium term increases in root growth to maximize water uptake [11].

The results also showed that under severe water stress, Anacardium occidentale plants from Ziguinchor maintained a high relative water content (RWC). The RWC is a widely used indicator to highlight the state of the water balance of a plant. It also assesses the ability to achieve good osmoregulation, and to maintain cell turgor [12]. RWC is closely related to cell volume and may closely reflect the balance between leaf water supply and transpiration rate [13]. Several works suggest that genotypes or cultivars that manage to maintain high RWC under water stress are drought tolerant genotypes [14, 15, 16].

The work of [17] on two provenances of Camptotheca acuminata showed that the provenance with higher drought tolerance had better water retention capacity, antioxidant enzyme activity and membrane integrity.

Also, according to [18], biomass measurement is one of the best factors to assess plant tolerance to water stress. Indeed, a decrease in biomass and plant height was observed with increasing drought stress levels in all four provenances tested. Similar results were observed in several species such as: rice [19] and wheat [20].

Our results showed higher biomasses in the Ziguinchor provenance compared to other provenances tested under water stress conditions. This provenance performed well when water is not limited with minimal biomass loss under drought stress conditions. The biomass of plant species is often determined by breeders to explore a pathway for the development of drought resistant cultivars. For example, the work of [21] on Pistacia vera L. cultivars showed better cultivar resistance with less biomass loss under drought conditions. Water stress, on the other hand, leads to a decrease in root characteristics [22]. A lower reduction in root length was noted in western Anacardium plants from the Ziguinchor provenance. These results confirm the better growth in height and total biomass in this provenance. Several studies have shown a correlation 
Vol. 06, No. 03; 2021

ISSN: $2456-8643$

between better root traits and drought tolerance in several plant species such as: orange [23]; Ziziphus and prunus [24] and Eucalyptus [25].

\section{CONCLUSION}

The water stress resistance of four Anacardium occidantale provenances was tested for 4 months under semi-controlled conditions. Anacardium occidentale provenances tested had different responses to the water stress condition. Plants from Ziguinchor provenance had a better survival rate and developed better height, biomass, root length and relative water content. According to our study, Ziguinchor provenance is better adapted to drought conditions and is recommended to producers to fight against the effects of climate change.

\section{REFERENCES}

[1] Huang, J., Zhang, W., Zuo, J., Bi J., Shi J., Wang X., Chang Z., Huang Z., Yang S., Zhang B., Wang G., Feng G., Yuan J., Zhang L., Zuo H., Wang S., Fu C., Jifan C., (2008) An overview of the Semi-arid Climate and Environment Research Observatory over the Loess Plateau. Adv. Atmos. Sci. 25, 906. https://doi.org/10.1007/s00376-008-0906-7

[2] Boyer, J., (1982) "Plant productivity and environment." Science, 2:18 443-448, doi: 10.1126/science.218.4571.443

[3] Lahmar R., Bationo B.A., Lamso N.D., Guéro Y., Tittonell P., (2012) Tailoring conservation agriculture technologies to West Africa semi-arid zones: Building on traditional local practices for soil restoration. Field Crops Research, Volume 132, Pages 158-167, ISSN 0378-4290, https://doi.org/10.1016/j.fcr.2011.09.013

[4] Shao H-B., Chu L.Y., Jaleel C.A., Manivannan P., Panneerselvam R., Shao M.A., (2009) Understanding water deficit stress-induced changes in the basic metabolism of higher plants - biotechnologically and sustainably improving agriculture and the ecoenvironment in arid regions of the globe, Critical Reviews in Biotechnology, 29:2, 131-151, DOI: $10.1080 / 07388550902869792$

[5] Shao H-B., Chu L.Y., Jaleel C.A., Zhao C.X., (2008) Water-deficit stress-induced anatomical changes in higher plants, Comptes Rendus Biologies, Volume 331, Issue 3, , Pages 215-225, ISSN 1631-0691, https://doi.org/10.1016/j.crvi.2008.01.002

[6] Schwabe K., Albia J., Connor J.D., Hassan R.M., González L.M., (2013) Drought in Arid and Semi-Arid Regions | eBook ISBN 978-94-007-6636-5, Springer, Dordrecht. s. d. Consulté le 16 avril 2021. https://link.springer.com/book/10.1007\%2F978-94-007-6636-5

[7] Totjssaint-Norlet, Giffard P., (1961) Les plantations de Darcassou (Anacardium occidentale L.) au Sénégal, ISRA, rapport n ${ }^{\circ} 1082 / 232 / 663,35 \mathrm{p}$

[8] Sané T., Benga A. et Sall O., (2010) La Casamance face aux changements climatiques : Enjeux et Perspectives. 23 ième Colloque de l'Association Internationale de Climatologie, Rennes 2010. 
Vol. 06, No. 03; 2021

ISSN: $2456-8643$

https://www.researchgate.net/publication/321529200_LA_CASAMANCE_FACE_AUX_CH ANGEMENTS_CLIMATIQUES_ENJEUX_ET_PERSPECTIVES

[9] Mbaye I., (2015) Perception des impacts du changement climatique et stratégie d'adaptation en milieu périurbain de la ville de Ziguinchor au Sénégal. VertigO - la revue électronique en sciences de l'environnement [En ligne], Volume 15 Numéro 1 | mai 2015, mis en ligne le 15 mai 2015, consulté le 16 avril 2021. URL : http://journals.openedition.org/vertigo/16005 ; DOI : https://doi.org/10.4000/vertigo.16005

[10] Djighaly P.I., Ndiaye S., Diarra A.M., Dramé F.A., Baldé B., (2020) Effet de la salinite sur le pouvoir infectif des champignons mycorhiziens a arbuscules et la diversite de la vegetation herbacee dans le perimetre rizicole de la vallee de Niamone (Ziguinchor, Senegal). Am. J. innov. res. appl. sci. 2020; 10(2):69-76

[11] Kramer, P.J. and Boyer, J.S., (1995). "Water relations of plants and soils." Academic Press, San Diego. Calif. USA, 1995, 495p

[12] Sanders G.J., Arndt S.K., (2012) Osmotic Adjustment Under Drought Conditions. In: Aroca R. (eds) Plant Responses to Drought Stress. Springer, Berlin, Heidelberg. https://doi.org/10.1007/978-3-642-32653-0_8

[13] Qariani, L., El-Jaafari, S., Dekkaki, M. et Araus, J.L., (2000). Cuticular conductance, water use efficiency and drought tolerance of durum wheat isolines of differing glaucousness In: Durum wheat improvement in the Mediterranean region. Zaragoza: CIHEAM-IAMZ; Options Méditerranéennes : Série A. Séminaires Méditerranéens, 40:315-318, http://om.ciheam.org/om/pdf/a40/00600044.pdf

[14] Parida, A.K., Dagaonkar, V.S., Phalak, M.S., Aurangabadkar L.P., (2008) Differential responses of the enzymes involved in proline biosynthesis and degradation in drought tolerant and sensitive cotton genotypes during drought stress and recovery. Acta Physiol Plant 30, 619-627. https://doi.org/10.1007/s11738-008-0157-3

[15] Siddiqui M.H., Al-Khaishany M.Y., Al-Qutami M.A., Al-Whaibi M.H., Grover A., Ali H.M., Al-Wahibi M.S., Bukhari N.A., (2015) Response of Different Genotypes of Faba Bean Plant to Drought Stress. International Journal of Molecular Sciences; 16(5):10214-10227. https://doi.org/10.3390/ijms160510214

[16] Khoyerdi F.F., Shamshiri M.H., Estaji A., (2016) Changes in some physiological and osmotic parameters of several pistachio genotypes under drought stress, Scientia Horticulturae, Volume 198, 2016, Pages 44-51, ISSN 0304-4238, https://doi.org/10.1016/j.scienta.2015.11.028

[17] Ying Y.Q., Song L.L., Jacobs D.F., Mei L., Liu P., Jin S.H., Wu J.S., (2015) Physiological response to drought stress in Camptotheca acuminate seedlings from two provenances. Front. Plant Sci. 6:361. doi: 10.3389/fpls.2015.00361 
[18] Füzy A., Kovács R., Cseresnyés I., Parádi I., Szili-Kovács T., Kelemen B., Rajkai K., Takács T., (2019) Selection of plant physiological parameters to detect stress effects in pot experiments using principal component analysis. Acta Physiol Plant 41, 56. https://doi.org/10.1007/s11738-019-2842-9

[19] Vijayaraghavareddy P., Vemanna R.S., Yin X., Struik P.C., Makarla U., Sreeman S., (2020) Acquired Traits Contribute More to Drought Tolerance in Wheat Than in Rice", Plant Phenomics, vol. 2020, Article ID 5905371, 16 pages,. https://doi.org/10.34133/2020/5905371

[20] Grzesiak S., Hordyńska N., Szczyrek P., Grzesiak M.T., Noga A., Szechyńska-Hebda M., (2019) Variation among wheat (Triticum easativum L.) genotypes in response to the drought stress: I - selection approaches, Journal of Plant Interactions, 14:1, 30-44, DOI: $10.1080 / 17429145.2018 .1550817$

[21] Esmaeilpour A., Van Labeke M-C., Samson R., Ghaffaripour S., Van Damme P. (2015) Comparison of biomass production-based drought tolerance indices of pistachio (Pistacia vera L.) seedlings in drought stress conditions. International Journal of Agronomy and Agricultural Research (IJAAR) Vol. 7, No. 2, p. 36-44, 2015 ISSN: 2223-7054

[22] Junjittakarn J., Girdthai T., Jogloy S., Vorasoot N., Patanothai A., (2014) Response of root characteristics and yield in peanut under terminal drought condition. Chilean journal of agricultural research, ISSN 0718-5839, http://dx.doi.org/10.4067/S071858392014000300001

[23] Gomes, M., Lagôa, A.M.A., Medina, Camilo L.M., Machado E.C., \& Machado M.A. (2004). Interactions between leaf water potential, stomatal conductance and abscisic acid content of orange trees submitted to drought stress. Brazilian Journal of Plant Physiology, 16(3), 155-161. https://dx.doi.org/10.1590/S1677-04202004000300005

[24] Arndt S., Livesley S., Merchant A., Bleby T., Grierson P., (2008) Quercitol and osmotic adaptation of field grown Eucalyptus under seasonal drought stress. Plant Cell Environ 31:915-924 https://doi.org/10.1111/j.1365-3040.2008.01803.x

[25] Arndt S., Wanek W., Clifford S., (2000) Contrasting adaptations to drought stress in fieldgrown Ziziphus mauritiana and Prunus persica trees: water relations, osmotic adjustment and carbon isotope composition. Functional Plant Biology 27, 985-996. https://doi.org/10.1071/PP00022 